\title{
Bezwstyd. Gejowski performans Jana Peszka
}

Grzegorz Niziołek

TEKSTY DRUGIE 2021, NR 2, S. 335-357

DOI: 10.18318/td.2021.2.20 | ORCID: 0000-0001-5082-8285

1.

Pojawienie się na scenie teatralnej w 1981 roku Gonzala, homoseksualnego bohatera Trans-Atlantyku Witolda Gombrowicza, należy do znaczących, ale zapomnianych teatralnych mikrozd a r z é polskiej sfery publicznej. Choć rola Jana Peszka stała się już legendą, pierwsze silne reakcje na jego gejowski performans zostały zapomniane. Pod terminem „teatralne mikrozdarzenie sfery publicznej" kryją się dwa istotne zjawiska: załamanie się stabilnej ramy teatru jako zasady analizy spektaklu podtrzymującej koncepcję spójności dzieła teatralnego oraz niekontrolowany incydent wtargnięcia w obszar scenicznej reprezentacji afektu związanego z nastawieniem widzów wobec zjawisk społecznych, których znaki zostają przez nich rozpoznane na scenie. Tego rodzaju naruszenie często ma charakter serii, zdarzenia dyskursywne mnożą się, rozgrywają się wedle podobnego wzoru - recenzje z polskiej prapremiery Trans-Atlantyku są zdumiewająco zbieżne w reakcjach na pojawienie się na scenie homoseksualnego bohatera. Próbuję zatem 
ukazanie się Gonzala postrzegać jako fakt bardziej o znaczeniu afektywnym i społecznym niż artystycznym. Zamierzam analizować performans Gonzala poprzez uruchomiony wokół niego bezprecedensowy, klecony ad hoc, dyskurs na temat homoseksualności (recenzje ukazały się zarówno w wysokonakładowej prasie codziennej, popularnych tygodnikach, jak i czasopismach literackich i teatralnych), a poprzez analizę tak ustanawianego dyskursu śledzić reakcje o charakterze afektywnym. Czytane w takiej perspektywie recenzje teatralne nie są już wyłącznie częścią dokumentacji spektaklu, lecz także śladem dyskursywnych praktyk związanych z tabuizowanymi kwestiami, takimi jak homoseksualność. A zatem praktyk spychanych na margines sfery publicznej lub całkowicie z niej usuwanych'

Wcześniejsza literacka recepcja powieści często pomniejszała znaczenie tej postaci, czyniła z niej element szerzej zakrojonej przez Gombrowicza alegorii przedstawiającej konflikt Starego z Młodym, Ojczyzny i Synczyzny. Konstanty Jeleński przyznawał po latach, że początkowo nie docenił znaczenia tej postaci, wagi jej strukturalnego umocowania w narracji powieściowej:

Dlaczego nie zauważyłem tego od razu? Może po części dlatego, że Gombrowicz nie przyznawał się jeszcze wówczas do swoich homoseksualnych doświadczeń (za które wziął otwarcie odpowiedzialność dopiero w napisanej do poświęconego mu numeru Herne nocie biograficznej²). Skądinąd nie ma cienia podobieństwa między Gombrowiczem a Gonzalem, który ma pozory rozlatanej, egzasperującej „cioty” (podczas gdy homoseksualna strona Gombrowicza miała wyraz zdecydowanie powściagliwy, ascetyczny). ${ }^{3}$

Homoseksualność Gombrowiczowskiej postaci - scenicznie ucieleśniona - wywołała kryzys nie tylko w interpretacji scenicznego dzieła, lecz także

1 O tym, że zjawisko to było odczytywane przez osoby homoseksualne jako zmowa milczenia, pisał Tomasz Basiuk: „Mimo (dość nielicznych) publikacji prasowych na ten temat, zawoalowanych aluzji literackich i pewnej liczby przekładów literatury obcej, a także okazjonalnego, zwykle prześmiewczego ukazywania homoseksualności na ekranie, rozmówcy często są zdania, że o tych rzeczach nie mówiło się" (T. Basiuk Od niepisanej umowy milczenia do protopolityczności: dyskursywny i sieciowy charakter społeczności osób homoseksualnych w "długich latach 70."W historii mówionej i epistolografii, "InterAlia” $2019 \mathrm{nr}$ 4, s. 32).

2 Monograficzny numer "Cahiers de l'Herne" ukazał się w 1971 roku, dwa lata po śmierci Gombrowicza.

3 K.A. Jeleński Tajny ładunek korsarskiego okrętu, "Kultura” 1976 nr 5, s. 26. 
w czytaniu znaczeń powieści przez pryzmat spektaklu. Tego rodzaju seryjnie powielony kryzys utraty kontroli nad dyskursem nazywam właśnie teatralnym mikrozdarzeniem sfery publicznej. Zdarzenie dyskursywne, zdaniem Michela Foucaulta, domaga się bowiem nie tyle odczytania, ile ujawnienia okoliczności swojego zaistnienia, prowadzi nas nie w głąb dyskursu, ku jego znaczeniom, ale na zewnątrz, ku „warunkom możliwości”“. Pojawienie się na scenie homoseksualnego mężczyzny domagającego się uznania swoich pragnień niejako przedziurawiło rutynowe strategie krytyczne: ujawniło działanie afektu i brak funkcjonalnego dyskursu pozwalającego ów afekt ujarzmić, uregulować lub uciszyć. Postać Gonzala zaskoczyła widzów, a efektem tego zaskoczenia była próba wyłączenia jego performansu z obszaru spektaklu oraz uznanie go za niezgodny z powieściowym pierwowzorem. Właśnie nadmiar afektu i niedostatek dyskursu leżą u podstaw konfliktowych mikrozdarzeń sfery publicznej. Recenzenci, nie bez emocji, konstatowali, że sens spektaklu ustanawia się w tym przypadku poza intencjami reżysera spektaklu i autora powieści, przebiega w sposób niekontrolowany i niezaplanowany. Stawiam tezę, że zaapelowanie do homofobii publiczności wydawało się recenzentom jedynym sposobem odzyskania władzy nad eksperckim dyskursem krytycznym, umożliwiało bowiem odcięcie się od niewygodnego faktu, jakim okazała się niekontrolowana siła gejowskiego performansu.

Istnieje tradycja, aby instytucję teatru publicznego i wynalazek sfery publicznej traktować jako zjawiska izomorficzne. Oświeceniowy model teatru publicznego można traktować jako jedną z kluczowych instytucji sfery publicznej. Dzięki wynalazkowi sfery publicznej teatr zyskał większą widownię - publiczność wyobrażoną, liczniejszą i bardziej znaczącą od grupy widzów fizycznie zgromadzonych podczas spektaklu. Izomorficzne złączenie instytucji teatru i sfery publicznej zakłada, że teatr podejmuje kwestie warte debaty w sferze publicznej, służy sprawom emancypacji i demokratyzacji i można go oceniać wedle kryterium wspierania postępowych zmian. Joanna Krakowska, redaktorka serii „Teatr publiczny. Przedstawienia 1765-2015", we wstępie do jednego z tomów definiuje przedstawienie jako dyskurs, kładąc nacisk na komunikacyjny aspekt wydarzenia teatralnego i jego związek ze sferą publiczną. Odcina się przy tym od zbyt naiwnie pojmowanej oświeceniowej utopii teatru publicznego mającego służyć „wspólnemu myśleniu, odczuwaniu i debatowaniu

4 M. Foucault Porzq̨dek dyskursu, przeł. M. Kozłowski, słowo/obraz terytoria, Gdańsk 2002, s. 38. 
o istotnych sprawach jednostek i zbiorowości ku pożytkowi wzajemnemu", podkreślając, że działanie teatru należy zawsze rozpatrywać „w kontekście życia publicznego z jego dynamiką, kryzysami, konfliktami, punktami zapalnymi, obsesjami, traumami"s.

Richard Sennett, analizując zjawiska przemiany sfery publicznej w XIX wieku, ważną funkcję przypisał teatrowi jako instytucji realizującej cele niezbieżne z kierunkiem tych przemian. Sposób konceptualizowania przez Sennetta relacji między teatrem a sferą publiczną pozwala wskazać na kilka miejsc zerwania oświeceniowego izomorfizmu dyskursów. Sennett pisze m.in. o zyskującym coraz większy wpływ na zachowanie widzów reżimie milczenia podczas spektaklu - wygłuszania i pozbawiania znaczenia reakcji widzów bezpośrednio uczestniczących w przedstawieniu. Towarzyszy temu zjawisku także wyciemnianie widowni. Milczenie widzów ma dla Sennetta aspekt pejoratywny - staje się oznaką zwątpienia w siebie, symptomem

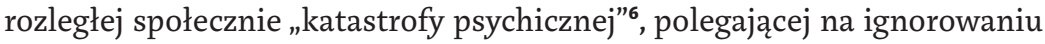
bądź tłumieniu żywotnych impulsów. Recenzent staje się w związku z tym zjawiskiem rzecznikiem widowni, uzurpującym sobie prawo do mówienia w jej imieniu. Kolejnym - pokrewnym - zjawiskiem omawianym przez Sennetta jest zwiększająca się rozbieżność między „kodami wiary obowiązującymi na scenie i ulicy". Im bardziej zachowania społeczne podlegały represji, kontroli i uniformizacji, tym bardziej teatr poszukiwał „barwnych osobowości" wyłamujących się z narzucanej zasady nieodróżniania się od innych. Chodziło jednak - jak podejrzewa Sennett - nie tyle o swobodną ekspresję uczuć i przekonań, ile o wytwarzanie skutecznych instrukcji rozpoznawania inności. „Publiczność zażądała, żeby przynajmniej w teatrze można było naprawdę i bez trudności określić na pierwszy rzut oka, kto jest kim"7.W takim ujęciu spektakl rozumiany jako dyskurs staje się narzędziem mediacji między milczeniem społecznym a nadmierną widzialnością tego, co inne, obce. Warto w tym kontekście przypomnieć ostrzeżenie Michela Foucaulta: „Dyskurs nie jest wspólnikiem naszego poznania, nie istnieje przeddyskursywna opatrzność, która przysposabiałaby go na naszą korzyść. Dyskurs postrzegać należy jako akt przemocy, którego dokonujemy na

5 J. Krakowska PRL. Przedstawienia, PIW, Instytut Teatralny im. Zbigniewa Raszewskiego, Instytut Sztuki PAN, Warszawa 2016, s. 13.

6 R. Sennett Upadek człowieka publicznego, przeł. H. Jankowska, Muza, Warszawa 2009, s. 286.

7 Tamże, s. 287. 
rzeczach, a w każdym razie jako praktykę, jaką im narzucamy"s. Podążając za inspiracją Foucaulta, należałoby uznać dyskurs za sposób ustanowienia nad nim władzy.

2.

Zdarzenie, o którym piszę, nastąpiło 23 maja 1981 roku w Teatrze im. Stefana Jaracza w Łodzi - w okresie emocji społecznych związanych z powstaniem Solidarności i zachwianiem dotychczasowego politycznego status quo. Prapremierę Trans-Atlantyku wyreżyserował Mikołaj Grabowski, rolę Gonzala zagrał Jan Peszek - dla obu młodych wówczas artystów był to moment zwrotny w karierze scenicznej, przyniósł im zainteresowanie krytyków, aplauz widowni, nagrody, nowe propozycje zawodowe. Wyodrębniam jednak pojawienie się Gonzala i jego sceniczny performans jako zdarzenie przerastające znaczenie samej inscenizacji, zyskujące własny kontekst i obszar oddziaływań, rozsadzające spójność spektaklu. Lektura recenzji pozwala na taki krok: performans Jana Peszka został uznany przez krytyków za najżywszy, ale i najbardziej niepokojący element spektaklu, jaskrawo odcinający się od tła i pozostałych, „polskich" (i w domyśle heteroseksualnych) postaci spektaklu. Taka nierównowaga w spektaklu wywoływała mieszane uczucia - z jednej strony podziwiano maestrię aktora, $\mathrm{z}$ drugiej wyrażano obawę, że przesunięcie akcentu zmienia sens powieści Gombrowicza, ponieważ widzowie zamiast oczekiwanej „rozprawy z Polską” otrzymują „spektakl o homoseksualizmie”.

Występ Jana Peszka nazywam gejowskim performansem, terminem nieznanym ówczesnym recenzentom i recenzentkom, aby celowo naznaczyć go piętnem ni e a k tu a ln o ści w chwili wydarzania się. Nieaktualność zwykle dotyczy czegoś, co utraciło znaczenie, definiuje stosunek teraźniejszości do przeszłości; w tym wypadku mowa o zdarzeniu, które jeszcze nie zyskało znaczenia. Pisząc o „performansie” Jana Peszka, odwołuję się do tych współczesnych teorii, które wiążą praktyki performansu z nasileniem oddziaływań afektywnych. Wątek ten jest obecny w rozważaniach m.in. Eve Kosofsky Sedgwick, Diany Taylor, Rebeki Schneider. Odwracam jedynie kierunek ich

8 M. Foucault Porządek dyskursu, s. 38.

9 E. Kosofsky Segdwick Touching Feeling: affect, pedagogy, performativity, Duke University Press, Durham 2003; D. Taylor The archive and the repertoire, Duke University Press, Durham-London 2003; R. Schneider Performing remains: art and war in times of theatrical reenactment, Routledge, London-New York 2011. 
rozumowania - zauważając silne afektywne oddziaływanie występu Jana Peszka w roli Gonzala, przeczuwam tam obecność performansu. Wpisując rolę Peszka w dyskursy emancypacyjne, diagnozuję równocześnie brak warunków społecznych do odczytania jego emancypacyjnego sensu w chwili jego zaistnienia, możliwości nadania mu znaczenia politycznego.

Język związany z doświadczeniami osób homoseksualnych był w tamtym czasie całkowicie sprywatyzowany, miał cechy mowy intymnej lub żargonu środowiskowego, nie przenikał do języka ogólnie dostępnego i zrozumiałego, chyba że w postaci terminologii medycznej; brakowało więc dyskursu publicznego, który pomógłby recenzentom Trans-Atlantyku podjąć rzetelną analizę spektaklu pod tym kątem. Poza tym teatr polski w tamtym okresie unikał tematyki emancypacyjnej, ciążył raczej ku ideom teatru narodowego, problematyce tożsamości zbiorowej, rewizjom historii narodowej ${ }^{10}$. Treści potencjalnie emancypacyjne zostały przesunięte w sferę tego, co prywatne - ich oddziaływanie polityczne było w ten sposób osłabione lub wręcz sparaliżowane.

W dekadzie poprzedzającej premierę Trans-Atlantyku wątki homoseksualne pojawiały się w teatrze w formach zawoalowanych. Dość wymienić Jerzego Grotowskiego (Apocalypsis cum figuris), Konrada Swinarskiego (Wszystko dobre, co się dobrze kończy), Henryka Tomaszewskiego (Przyjeżdżam jutro), Andrzeja Wajdę (Biesy), Erwina Axera (Dawne czasy), Helmuta Kajzara (+++) czy debiutującego pod koniec lat 70. Krystiana Lupę (Nadobnisie i koczkodany). W recepcji wymienionych spektakli dominowały język niedomówień, aluzji i strategia przemilczeń. Wszystkie jednak diagnozowały stan społecznego napięcia wobec nasilających się dążeń emancypacyjnych ruchów gejowskich w Europie i Stanach Zjednoczonych, równocześnie je przemilczając (pamiętajmy, że mówimy o artystach pozostających w tym czasie w żywym kontakcie z kulturą Zachodu). Znając skalę, zasięg i znaczenie gejowskiej rewolty na Zachodzie po 1968 roku"1 , trzeba stwierdzić, że nie miała ona żadnego odpowiednika w Polsce i nie przedarła się u nas do szerszej świadomości społecznej. Wątki homoseksualne pojawiały się w polskim teatrze tamtego czasu bez udziału komponentów tożsamościowych - żaden z twórców ani krytyków nie

10 Por.: D. Kosiński Teatra polskie. Historie, Wydawnictwo Naukowe PWN i Instytut Teatralny im. Zbigniewa Raszewskiego, Warszawa 2010; G. Niziołek Polski teatr Zagłady, Wydawnictwo Krytyki Politycznej i Instytut im. Zbigniewa Raszewskiego, Warszawa 2013.

11 Por. J. Weeks Coming out: homosexual politics in Britain from the nineteenth century to the present, Quartet Books, London-New York 1977, s. 185-206. 
ujawniał własnej orientacji seksualnej, nie odnosił się do kwestii zachodniej kultury gejowskiej ani tym bardziej do życia szczelnie zakonspirowanych środowisk polskich homoseksualistów. Odwoływano się raczej do dobrze przyswojonych w polskiej kulturze modernistycznych strategii podwójnego kodowania, unikania kwestii tożsamościowych i akcentowania treści psychologicznych. Nawet w artykułach prasowych na temat homoseksualizmu, które ukazały się w Polsce w tamtym czasie i są dziś uznawane za przełomowe w ustanawianiu nowych postaw społecznych, ich autorzy i autorki wyrażali dystans wobec emancypacyjnych dążeń ruchu gejowskiego na Zachodzie. Kilka miesięcy przed premierą Trans-Atlantyku ukazał się na łamach „Polityki” głośny reportaż Barbary Pietkiewicz Gorzki fiolet ${ }^{12}$. Autorka wypowiada się w nim przeciwko penalizacji homoseksualizmu i traktowania odmiennej orientacji seksualnej jako „zboczenia”, wzywa też do empatii wobec cierpień osób homoseksualnych. W finale tekstu dystansuje się jednak od emancypacyjnych dążeń ruchów gejowskich: „Tolerancja nie może oznaczać aprobaty ani przyznania specjalnych uprawnień".

Gombrowiczowski Gonzalo w interpretacji Jana Peszka mógł być traktowany jako karykaturalne wyobrażenie wyemancypowanego zachodniego "gaya" i może dlatego spowodował ujawnienie postaw homofobicznych na skalę do tej pory chyba w polskiej kulturze niespotykaną. Trzeba pamiętać, że premiera Trans-Atlantyku odbyła się między powstaniem ruchu Solidarności w sierpniu 1980 roku a wprowadzeniem stanu wojennego w grudniu 1981, w czasie rozwijającej się w Polsce konserwatywnej rewolucji łączącej wątki populistyczne, narodowe i katolickie ${ }^{13}$, a zarazem w interwale poluzowanych nacisków cenzuralnych. Recenzenci nie byli przygotowani na żądanie emancypacyjne, jakie wypowiadał na scenie Gonzalo Peszka.

Najbardziej symptomatyczna wydaje się opublikowana na łamach miesięcznika literackiego „Twórczość” recenzja Marty Fik, wybitnej krytyczki, przenikliwej i trzeźwej w ocenach, cenionej i szanowanej, zainteresowanej teatrem politycznym. Fragment poświęcony postaci Gonzala i roli Jana Peszka ujawnia jednak dyskursywną bezradność autorki:

Gubi się przede wszystkim sens zasadniczej dla powieści opozycji Synczyzna - Ojczyzna. Cały wątek uwodzenia Ignaca (Mariusz Wojciechowski) przez „pedka” Gonzala nabiera efektownej, lecz irytującej

12 B. Pietkiewicz Gorzki fiolet, „Polityka” 1981 nr 8, s. 8.

Por. M. Kula Narodowe i rewolucyjne, Aneks i Biblioteka "Więzi", Londyn-Warszawa 1991. 
dosłowności. Duży w tym udział odtwórcy roli Gonzala Janusza ${ }^{14}$ Peszka, który swym dynamizmem, sugestywnością środków - sugestywnością wiodącą czasem aż na manowce grania „pod publiczkę" - usuwa w cień wszystkich pozostałych aktorów, nawet tych najbardziej tu interesujących, jak wspomniany już Władysław Dewoyno czy Bogusław Sochnacki Minister Kosiubidzki - a wraz z aktorami przynależne im epizody. Sam wątek związany z Gonzalem traci swą pretekstowość, gdzieś tam w tle ledwie rysuje się sprawa wyzwalania Młodości spod tyranii Starego, i pozostaje tylko anegdota - zabawna, choć dość śmiała jak na przyzwyczajenia polskiej publiczności. Publiczności, która od dość dawna nie zgłasza już sprzeciwu wobec różnorakich golizn, dwuznacznych dialogów, a nawet drastycznych wyrażeń, która jednak wciąż jeszcze wobec sprawy zboczeń seksualnych zajmuje stanowisko niezbyt dalekie od tego, jakie prezentował Ojciec z Trans-Atlantyku.W tym jednym punkcie inscenizacja może ją poruszyć, pod tym tylko względem Trans-Atlantyk zachował swoją prowokacyjność...

I to wydaje się najbardziej paradoksalne. Patrząc na obecną widownię - i tę zgorszoną, i tę snobistycznie zasłuchaną - autor Trans-Atlantyku nie odczuwałby zapewne satysfakcji. Jeśli nawet uznać, że dzieło to wciąż jeszcze warte jest prezentacji i to w teatrze, nie sposób nie zgodzić się $\mathrm{z}$ tym, że straciło całą swą istotną ostrość. ${ }^{15}$

Na wstępie trzeba odnotować charakterystyczny i powszechny wówczas problem terminologiczny - jak pisać o homoseksualistach, jak ich nazywać wobec braku stosownych konwencji społecznych oraz konieczności lawirowania między homofobicznym żargonem, językiem medycznym i eufemizmami? Gonzalo zostaje najpierw nazwany poufale „pedkiem” - wzięte w cudzysłów słowo sugeruje, że nie należy ono do słownika autorki, zostało doraźnie zapożyczone z mowy potocznej, niemal żargonowej. Być może w opinii autorki "pedek" pasuje do tego typu „przegiętego" homoseksualisty, jakiego przedstawił na scenie Peszek, a być może jest to tylko rodzaj ucieczki przed zbyt oficjalnie brzmiącym słowem „homoseksualista”. Pozwala jednak też zdystansować się Marcie Fik wobec tej postaci, umieścić poza granicami jej świata. W ten sposób recenzentka staje się rzeczniczką zgorszonej widowni i choć z jednej

14 Jan Peszek do 1979 roku pojawiał się na afiszu jako Janusz Peszek, część recenzentów wciąż używała tego imienia, mimo że w Trans-Atlantyku aktor występuje już jako Jan Peszek. 
strony pokpiwa z nadmiernej jakoby tolerancji ówczesnych widzów wobec różnego rodzaju treści seksualnych („różnorakich golizn”), z drugiej zdaje się w pełni rozumieć - a nawet podzielać - ich opór wobec manifestowanej przez Gonzala homoseksualności. Istnieje tutaj dysonans pomiędzy lekceważącym potraktowaniem tematyki seksualnej, zrównaniem homoseksualności z modą na "goliznę" a przygważdżającym terminem „zboczenie seksualne". Autorka wydaje się nie odczuwać ciężaru użytego przez siebie sformułowania, jego piętnującej mocy - nie jest chyba świadoma zmiany, jaka nastąpiła w latach 70. XX wieku wśród seksuologów wobec zjawiska homoseksualności (m.in. pod wpływem wykreślenia przez Amerykańskie Towarzystwo Psychiatryczne homoseksualizmu z listy zaburzeń). To, że widzowie wrogo odnoszą się do tematu „zboczeń seksualnych”, nie dyskredytuje ich w oczach Marty Fik - wina raczej spada na teatr, który akcentując wątek homoseksualny, odwrócił uwagę publiczności od „istotnych” problemów powieści. Co więcej, Fik kojarzy odczuwane przez siebie nastawienie widowni względem Gonzala z postawą Ojca, bohatera powieści, rzecznika i symbolu narodowego tradycjonalizmu. Rolę Ojca w wykonaniu Władysława Dewoyny uważa za jedną z najbardziej „interesujących” w spektaklu i ma za złe Peszkowi, że ją przesłonił swoją kreacją. I nawet jeśli poglądy Ojca na kwestie „zboczeń seksualnych" uważa za przestarzałe i konserwatywne, odczuwa dla nich większe zrozumienie niż dla irytującej ją obecności wątku homoseksualnego. Sugeruje rozłam na widowni - na zgorszonych i snobistycznych widzów, ale siebie stawia ponad tym podziałem, nie znajdując zarazem innego rozwiązania sugerowanego konfliktu niż sprowadzenie postaci Gonzala i jego homoseksualności z powrotem do charakteru „pretekstowego”. Brak zgorszenia Fik interpretuje jako snobizm ${ }^{16}$, nie dopuszczając żadnej pozytywnie waloryzowanej odpowiedzi na postać Gonzala. Zauważając, że homoseksualny wątek powieści Gombrowicza stał się w spektaklu najbardziej prowokacyjny, stara się równocześnie go zignorować. Waha się, czy odpowiedzialnością obarczyć widownię (nie dość tolerancyjną wobec kwestii „zboczeń seksualnych” i przez to nadmiernie skupiającą uwagę na gorszącym ją wątku), czy twórców spektaklu, zwłaszcza Jana Peszka, który zbyt „efektownie” i „pod publiczkę" zagrał postać Gonzala.

16 Zbigniew Lew-Starowicz, odpowiadając jednemu z czytelników na jego niepokoje związane z własną orientacją seksualną, przestrzegał, że jedną z przyczyn homoseksualizmu może być snobizm. Pisze o tym Agnieszka Kościańska w monografii Zobaczyć łosia. Historia polskiej edukacji seksualnej od pierwszej lekcji do internetu, Czarne, Wołowiec 2017, s. 220. 
Marta Fik postawiła tezę, że nadmierne wyeksponowanie homoseksualności Gonzala zakłóciło interpretację spektaklu, odwróciło uwagę widzów od problematyki powieści. Działanie afektu przeniosło konflikt opisany w powieści Gombrowicza ze sceny na widownię. Sednem kryzysu dyskursywnego w zacytowanym fragmencie recenzji Marty Fik jest nierozpoznanie homofobii jako nastawienia społecznego deformującego znaczenia spektaklu i powieści, i co więcej - nieuznanie homofobii za rzecz godną napiętnowania. W tryb analizy krytyczno-teatralnej wmieszał się nierozpoznany przez autorkę homofobiczny język - jedyny zrozumiały, uznawany za neutralny i rozpowszechniony wówczas dyskurs na temat homoseksualności.

Trzeba od razu jednak zaznaczyć, że stanowisko Marty Fik w niczym nie odbiegało od ocen i postawy pozostałych recenzentów. Marian Sienkiewicz: „Łódzki spektakl, zrealizowany miejscami brawurowo, uległ zwichnięciu przez złe obsadzenie postaci Gombrowicza-narratora. Zepchnął ją na dalszy plan Gonzalo w koncertowym wykonaniu Jana Peszka, balansującego na śliskiej granicy kabaretowej zgrywy... Podejrzewam, że dla wielu widzów sceniczny Trans-Atlantyk jest w odbiorze po prostu rzeczą o homoseksualizmie"17. Ewa Piotrowska: "ma się chwilami wrażenie, że spektakl niesie przestawienia interpretacyjne zbyt bardzo w duchu dewiacji i egzotyczności, za mało w duchu historiozofii Gombrowicza"18. Krystyna Starczak-Kozłowska: „W tej sytuacji wyrasta nadspodziewanie inny bohater: pederasta Gonzalo w interpretacji Jana Peszka. [...] Dzięki takiemu układowi wymowa adaptacji nabiera charakteru trochę dwuznacznego, do rangi głównej sprawy urasta bowiem problem: czy pederasta zdobędzie syna bogobojnego polskiego szlachcica (gra go gościnnie Władysław Dewoyno), czy też ów ojciec zdoła go wydrzeć pederaście?”' Henryk Pawlak: „Wyuzdany Gonzalo dobrze wie: żeby zdobyć ukochanego Ignasia, musi pokonać właśnie tę barierę. W realizacji scenicznej Mikołaja Grabowskiego omawiany wątek jest szczególnie wyeksponowany"20. Uderza w tych cytatach niepodważalne przekonanie, że temat homoseksualizmu jest czymś trywialnym, niewartym uwagi teatru, niewymagającym namysłu. Kilku recenzentów, podobnie jak Marta Fik, zakłada, że sympatie widzów lokują się po stronie Ojca. Warto zwrócić uwagę

\footnotetext{
M. Sienkiewicz Przekrój teatralny, „Przekrój” 1981 nr 1893, s. 9.

E. Piotrowska „Kwartet” czyli o świadomości i bezmyślności , "Nurt” 1981 nr 12, s. 40.

K. Starczak-Kozłowska Wobec przeszłości, „Fakty” 1981 nr 25, s. 10.

H. Pawlak Porachunek z Polskq słabq , "Głos Robotniczy" 1981 nr 115, s. 6.
} 
na epitety, jakimi Gonzalo Peszka jest obdarzany w recenzjach: „odrażający, oślizgły”, „wyuzdany”, , epatujący łapczywością na uciechy cielesne”. Niemal bezdyskusyjnie zakłada się, że mimo „efektowności” roli Peszka jego Gonzalo wzbudza na widowni nastawienia negatywne, bliskie obrzydzeniu. I to one wpływają na ostateczną wymowę spektaklu. Jerzy Katarasiński: „Widz, choć z pobłażliwym uśmieszkiem patrzy na towarzystwo «ojczyźniane» wraz z Ojcem, wybiera ten właśnie obóz, za którym stoją jakieś jednak racje, a nie obóz reprezentowany przez Gonzala, który kojarzy mu się wyłącznie z amoralnym chaosem. Tam są racje może wątpliwe, ale są, tu zaś - nie ma żadnych racji. Tak, wydaje mi się, wygląda to od strony widowni"21. Dalej rzecz zyskuje pewien stopień drastyczności, gdy recenzent w imieniu widowni zaczyna fantazjować o śmierci Gonzala:

Zamiast więc dylematu moralnego na scenie pozostaje płaska już zagadka związana z niepewnością - kogo Gombrowicz przeznaczył na zabicie. Kto kogo zabije - Ojciec - Syna, czy Syn - Ojca. Sympatia widowni pozostaje, to już logiczne, po stronie Ojca, którego gotowa byłaby łatwiej rozgrzeszyć (gdyby trzeba było wybierać) niż Syna. Tak naprawdę jednak - i tu, z punktu widzenia autora Trans-Atlantyku zacząłby się chyba absurd - widownia ma nadzieje, że w końcu autor wytnie jakąś sztuczkę, która pozwoli zabić nie kogo innego, ale Gonzala! I w tym momencie dylemat kończy się definitywnie, namacalnie jakby. Sprawa przestaje dotyczyć drogi, jaką ma iść Syn (i o co pyta Gombrowicz), zaczyna dotyczyć Gonzala - sprawcy zła wszelkiego. ${ }^{22}$

Dyskursywna niezdarność tego fragmentu ma posmak regresji kulturowej do mechanizmów wyławiania kozła ofiarnego. Rozważania na temat tego, po czyjej stronie opowiada się widownia i komu życzy śmierci, mają jednak nieocenioną wartość w tropieniu afektów wywołanych gejowskim performansem Peszka. Fantazje edypalne, uruchomione przez Gombrowicza w Trans-Atlantyku, znajdują tutaj jednoznacznie konserwatywne rozwiązanie. Ojciec jest nietykalny i ma przywilej władzy nad życiem Syna. Zagrożenie, jakie ta władza może wytwarzać (ojcobójstwo lub synobójstwo), zostaje rozładowane przez wskazanie na figurę obcego. Przekierowanie wrogości na postać homoseksualisty pozwala zażegnać kryzys relacji edypalnej.

21 J. Katarasiński Trans-Atlantykiem z prozy na scenę, "Odgłosy" 1981 nr 25, s. 11. 
3.

Michel Foucault proponował, aby pojęcia „świadomości i ciagłości” oraz „znaku i struktury” zastąpić przy analizie dyskursów pojęciami „wydarzenia i serii"23. Zwracał uwagę na takie zjawiska, jak regularność, prawdopodobieństwo, odchylenie, nieciągłość, transformacja, przypadek. Dyskursy stają się w ten sposób „zbiorem wydarzeń", a nie „przedstawieniami”. Foucault rozróżnia dwie grupy analiz dyskursów: „zbiór krytyczny”, pozwalający uchwycić „formy wykluczenia, ograniczenia, przystosowania”, oraz „zbiór genealogiczny", który bada, w jaki sposób systemy przymusu uformowały serie określonych dyskursów. Recenzje teatralne są zwykle traktowane jako dokumenty wartościowe wyłącznie dla historyków teatru - szybko znikają w czeluściach archiwów, nieprzydatne jako świadectwa historii innej niż historia teatru. Zajmowanie się homofobią w jej wymiarze kulturowym pozwala dostrzec przydatność postulatu badań genealogicznych. Genealogia zrywa z idealistycznymi wyobrażeniami o kulturze, wskazuje na jej uwikłanie w przemoc, tropi rozproszone sceny dyskryminacji i wykluczenia, ,sprzeciwia się rozwijaniu idealnych znaczeń”, odtwarza „różne systemy ujarzmienia”. Nie chodzi jednak o monotonne odkrywanie wciąż tego samego wzoru dominacji, lecz o możliwość uczestniczenia w „ryzykownym zdarzeniu”, wymuszającym „podjęcie nowej gry”.W tym sensie pole dyskursywne spektaklu z przeszłości może zawsze zostać na nowo otwarte.

George Weinberg, amerykański psycholog i psychoanalityk, tworząc w połowie lat 6o. XX wieku pojęcie „homofobii”, dokonał przewrotu kopernikańskiego ${ }^{24}$. Podkreślał, że to nie homoseksualizm, ale homofobię powinno się leczyć. Oskarżył amerykańskie środowisko psychoanalityczne o stygmatyzujące praktyki. Weinberg definiował homofobię jako „strach przed przebywaniem w bliskim kontakcie z homoseksualistami". Pojęcie to szybko zyskało znacznie rozleglejsze znaczenia polityczne, odegrało ważną rolę w tworzeniu kontrkulturowej świadomości na Zachodzie, wzmocniło rewolucyjną retorykę rodzącego się ruchu gejowskiego. Krytycy Weinberga podważali afektywny aspekt jego definicji, zwracali uwagę, że podstawą wrogości względem osób homoseksualnych jest bardziej system przesądów społecznych niż osobiste

M. Foucault Porządek dyskursu, s. 43. inspiracji określenie to pojawiło się po raz pierwszy w druku w felietonie Jacka Nicholsa i Lige'a Clarke'a w majowym numerze magazynu "Screw" w 1969 roku. Sam Weinberg użył w druku terminu "homofobia" w artykule opublikowanym w tygodniku "Gay" 19 czerwca 1971 roku. 
nastawienie ${ }^{25}$.Zarzucano Weinbergowi zbyt patologizujące ujęcie tego zjawiska.Wskazywano też,że afektywna podstawa homofobii jest znacznie szersza, mieści się w niej nie tylko lęk, lecz także złość, obrzydzenie, nienawiść, wstyd. Za szczególną odmianę homofobii zostały uznane również jej autoagresywne, uwewnętrznione formy - odczuwane przez osoby homoseksualne wobec samych siebie.

Badacze praktyk homofobicznych kładą nacisk na to, aby mówić raczej o homofobiach niż homofobii, uhistoryczniać to pojęcie, odczytywać je zawsze na lokalnym gruncie społecznym, krytycznie definiować je za każdym razem na nowo i nie obciążać funkcją miernika zacofania i postępu społecznego. Homofobię można traktować jako zły afekt, brzydkie uczucie, symptom, przesąd, utrwalony system dyskryminacji; może mieć charakter instytucjonalny, ideologiczny i personalny. Ma też jednak aspekt kulturotwórczy: wytwarza specyficzne formy komunikacji między osobami homoseksualnymi a ich otoczeniem. Jak zauważyli Louie Crew i Rictor Norton, „literatura homoseksualna jest pisana, czytana, krytykowana i studiowana w ogólnie wrogim środowisku"26. Wrogość jest tutaj rozumiana także jako odmowa zrozumienia, chęć odizolowania się, obojętność, a nie tylko jako jawnie manifestowana agresja. „Dopóki autorzy homoseksualni piszą dla publiczności, która w dużej mierze składa się z wrogich heteroseksualistów, muszą jakoś dostosować swoje dzieło do oczekiwań tej publiczności"27. Napięcie między homoseksualnym pisarzem a homofobicznym otoczeniem sprzyja wytwarzaniu nowych kodów artystycznych, które Harold Beaver nazywa „przeciw-kodami". Jego zdaniem homoseksualiści nie tworzą kultury alternatywnej, lecz zduplikowaną, w której znaki stają się „dwulicowe” i ślizgają się „tam i z powrotem po chwiejnej linii", a sam pisarz staje się „tajnym agentem", "rozdwojonym dealerem" ${ }^{28}$.

G.M. Herek Beyond "homophobia": thinking about sexual prejudice and stigma in the twenty-first century, "Sexuality Research \& Social Politics" 2004 vol. 1, no. 2; D.C. Kimmel Homophobia, w: Encyclopedia of applied psychology, ed. by C. Spielberger, Elsevier Academic Press, Amsterdam-Boston 2004, t. 2, s. 209-214; F. Lyonga Shades of homophobia: a framework for analyzing negative attitudes toward homosexuality, " Journal of Homosexuality" December 2019; ।. O'Brien Complicating homophobia, "Sexualities” 2008 vol. 11, no. 4; D. Wickberg Homophobia: on the cultural history of an idea, "Critical Inquiry" vol. 27, no. 1. Tamże, s. 274. 
Homofobiczne podłoże twórczości Witolda Gombrowicza nie zostało dotąd należycie przebadane ${ }^{29}$. Związane jest to zapewne z silnym upolitycznieniem tego pojęcia ( $\mathrm{z}$ tego powodu wydaje się ono nieadekwatne do analizy dzieł artystycznych), ale badania nad homofobią mają również skrzydło antropologiczne i kulturowe. Przed podjęciem próby odczytywania Gombrowicza w perspektywie polityki tożsamości przestrzegał German Ritz: „Wędrówka przez labirynt pożądania - jeżeli nie ma prowadzić do bezużytecznej destrukcji i demitologizacji autora - nie powinna rozbijać semantycznej ambiwalencji, stanowiącej podstawową figurę w twórczości Gombrowicza, powinno natomiast otworzyć jej kolejny wymiar lub lekturę"30. Wiadomo, że Gombrowicz bronił się przed etykietą „homoseksualisty”, mówił o swojej płynnej seksualności, fascynacji młodością bez względu na jej płeć: „Osobom, które by to interesowało, pragnę wyjaśnić, że nigdy, z wyjątkiem sporadycznych przygód w bardzo wczesnym wieku, nie byłem homoseksualistą" ${ }^{31}$. Wzorem dlań był Proust, który nigdy nie przyznał się do homoseksualizmu i, co więcej, nigdy nie przedstawiał go w pozytywnym świetle. Został zresztą z tego powodu oskarżony przez André Gide'a o popełnienie „występku przeciw prawdzie" ${ }^{\text {"32 }}$. Proust z kolei odpowiedział Gide'owi, że „o homoseksualizmie można pisać tak długo, jak nie przypisuje się go samemu"33. Ustalenia Klementyny Suchanow, biografki Gombrowicza, rozwiewają te opary pisarskiej automistyfikacji: czytamy w jej książce, że Gombrowicz stał się w Argentynie niestrudzonym łowcą homoseksualnych przygód, przytaczane przez nią fakty raczej nie pozwalają podtrzymać tezy o jego biseksualności ${ }^{34}$. Suchanow rzeczowo punktuje zachowania Gombrowicza świadczące o problemie z akceptacją własnej homoseksualności, zawstydzeniu i skrępowaniu, a także niechęci wobec mężczyzn mniej w tej kwestii pruderyjnych.

29 Wzorem do podjęcia takich badań mogłyby być książki Eve Kosofsky Sedwich (Between men: English literature and homosocial desire, Columbia University Press, New York 1985) i Heather Love (Feeling backward: loss and the politics of queer History, Harvard University Press, Cambridge, MA-London 2007).

G. Ritz Nić w labiryncie pożq̨dania. Gender i płeć w literaturze polskiej od romantyzmu do postmodernizmu, przeł. B. Drąg, A. Kopacki, M. Łukasiewicz, Wiedza Powszechna, Warszawa 2002, s. 197. W. Gombrowicz Dziennik, t. 1: 1953-1958, Wydawnictwo Literackie, Kraków 2007, s. 208. Tamże, s. 69 .

K. Suchanow Gombrowicz. Ja, geniusz, t. 1-2, Czarne, Wołowiec 2017. 
German Ritz ma częściowo rację - wskazanie homofobicznych klisz, którymi posługuje się Gombrowicz w Trans-Atlantyku, musi chwilowo zawiesić tryb lektury bardziej złożonej. Ale wbrew jego obawom pozwala też do niej wrócić. Trójkąt, w którym przepływa homoseksualne pragnienie, tworzą w powieści Gonzalo, Ignacy oraz narrator Witold. Gonzalo działa aktywnie na rzecz realizacji swojego pożądania, uwodząc Ignaca. Ignacy wydaje się seksualnie uśpionym i biernym obiektem cudzego pożądania. Witold jest figurą najbardziej ambiwalentną: skrycie dzieli z Gonzalem pragnienie seksualnego zbliżenia z Ignacym, ale jawnie okazuje dystans, a nawet wrogość wobec Gonzala. Homofobiczne wzorce w tak ujętym trójkącie pożądania realizowane są dwustopniowo. W pierwszym odnoszą się one do stereotypów społecznych na temat homoseksualności, która jest postrzegana jako objaw dekadencji kulturowej, zazwyczaj przypisywanej obcym kulturom i społeczeństwom (Gonzalo jest Argentyńczykiem). Jej podstawowym modelem jest uwiedzenie młodego chłopca przez dorosłego mężczyznę, a zatem genezą homoseksualności jest łańcuch deprawacji (Ignacy uwiedziony przez Gonzala sam może się stać deprawatorem innych), stąd już tylko krok do myślenia o homoseksualizmie w kategoriach zarazy moralnej. Wszystkie te homofobiczne klisze uruchomione przez Gombrowicza w Trans-Atlantyku pojawiają się w konserwatywnych dyskursach na temat homoseksualności (dość przypomnieć amerykańskie filmy edukacyjne z lat 50. XX wieku, mające chronić młodych chłopców przed uwiedzeniem przez starszych mężczyzn). Drugi stopień tworzą modele homofobii uwewnętrznionej. Gonzalo, choć podąża za swoimi pragnieniami, okazuje przejawy nienawiści do samego siebie, prowadzi grę z własnym wstydem, przyjmuje ze zrozumieniem pogardę otoczenia. Witold z kolei wydaje się zaniepokojony własnymi pragnieniami, tłumi je, podążą za nimi ukradkiem, jak choćby w scenach nocnych wizyt w pokoju Ignacego. Choć czuje sekretną więź z Gonzalem i jego pożądaniem, chętnie manifestuje wobec niego wyższość i pogardę. Ignacy mógłby natomiast być uznany za uosobienie niewiedzy o własnej homoseksualności ${ }^{35}$.

35 O mechanizmach wycofywania homoseksualnego pożądania z obszaru świadomości za sprawą różnych form represji pisał Guy Hocquenghem w kanonicznej dziś książce Le désir homosexuel wydanej w 1972 roku (wyd. anglojęzyczne: G. Hocquenghem Homosexual desire, Duke Univeristy Press, Durham-London 1993). Pisze o tym zjawisku także Tomasz Basiuk w cytowanym już artykule: „Mechanizm obronny uniemożliwiający uświadomienie sobie własnych homoseksualnych skłonności można postrzegać jako uwewnętrznienie powszechnej umowy milczenia" (s. 33). 
Te podwojone modele - homofobii strukturalnej i homofobii afektywnej, homofobii społecznej i homofobii uwewnętrznionej - tworzą w powieści Gombrowicza złożony układ elementów wzajemnie się napędzających. Znajdujemy zatem w Trans-Atlantyku niemal komplet homofobicznych klisz i w związku z tym możemy zapytać o ich oddziaływanie na czytelników. Wiele oczywiście zależy od warunków i okoliczności lektury. Przykład spektaklu Mikołaja Grabowskiego pokazuje, że mogą być one odczytane całkiem dosłownie i skutecznie sterować reakcjami widzów. Można też jednak w nich zobaczyć autoreferencyjny potencjał, pozwalający wniknąć w mechanizmy homofobii - właśnie jako zjawiska pełnego ambiwalencji, tak wysoko cenionej przez Germana Ritza w twórczości Gombrowicza.

Sposoby interpretacji Trans-Atlantyku tworzą dwa wyraźnie dominujące modele: jeden z nich polega na lekturze alegorycznej, uniwersalizującej i intertekstualnej ${ }^{36}$; drugi narodził się pod wpływem studiów queerowych, eksponujących problematykę płynnej tożsamości, denaturalizacji ról genderowych i podkreślających znaczenie strategii subwersywnych ${ }^{37}$. Żaden z tych modeli nie uwydatnia jednak dynamiki homofobicznych wzorców ujawnionych przez Gombrowicza w Trans-Atlantyku, wprost przeciwnie - brane są one w nawias, przemilczane. Pierwszy model, interpretacji alegorycznej, zamienia Gonzala w figurę ożywianą tylko dialektyką jej konfliktu z Ojcem. Drugi przekształca go w postać mesjańską, wyzwalającą innych z pęt skostniałych tożsamości. Żaden z tych trybów lektury nie podąża krytycznie za wątkami homofobicznymi obecnymi w powieści. Tryb alegoryczny chętnie przejmuje homofobiczne wzory opisu Gonzala jako adekwatne do charakteru i funkcji tej postaci. Lektura queerowa natomiast umieszcza zachowania homofobiczne wyłącznie w zewnętrznym wobec Gonzala świecie społecznym, nie rozważa współodpowiedzialności Gombrowicza za ich powielanie.

Aby uzmysłowić, jak w ówczesnej Polsce mógł być odbierany wątek uwodzenia Ignaca przez Gonzala, warto sięgnąć do reportażu Ewy Berberyusz Seks heroiczny, czyli polski, opublikowanego w roku premiery

Modelowym przykładem takiej interpretacji jest studium Stefana Chwina "Trans-Atlantyk" wobec "Pana Tadeusza”, "Pamiętnik Literacki” 1975 z. 4. dzoziemca i barokowa fałda. Przynależność narodowa a homoseksualizm w "Trans-Atlantyku” Witolda Gombrowicza, w: Grymasy Gombrowicza. W kręgu problemów modernizmu, społeczno-kulturowej roli płci i tożsamości narodowej, red. E. Płonowska-Ziarek, Universitas, Kraków 2001. 
Trans-Atlantyku. Autorka skierowała do kilku wybranych osób zestaw pytań dotyczących seksualności. Jedno z nich brzmiało: „Co by Pan(i) czuł, gdyby Pański syn okazał się homoseksualistą”. A oto odpowiedzi. Julian Godlewski (seksuolog, dyrektor Zakładu Seksuologii AM w Krakowie): „Zdumienie”. Andrzej Jarczewski (doktor habilitowany, seksuolog): „Powiem szczerze: zbyt dobrze znam to środowisko, bym się nie bał, czy się nie wykolei”. Mikołaj Kozakiewicz (filozof, etyk, pedagog): „Byłbym zaniepokojony i usiłowałbym go przeorientować seksualnie". Artur Sandauer (profesor literaturoznawstwa): „Nie byłbym zadowolony ze względu na brak potomstwa”. Elżbieta Sujak (psychiatra): „To byłaby złożona sytuacja emocjonalna: doznałabym poczucia winy za popełnione błędy wychowania seksualnego, przez które nie zdołałam uchronić swego dziecka przed uwiedzeniem homoseksualnym (człowiek nie rodzi się homoseksualistą, lecz nim zostaje), po drugie, byłoby mi żal, że może zostać pozbawiony trwałych więzi rodzinnych, a zwłaszcza radości ojcostwa - i po trzecie, bałabym się, że wobec panującej w środowisku homoseksualistów anarchii seksualnej zagrożony jest wykolejeniem i wyobcowaniem społecznym". Zapytani przez Berberyusz przypadkowi przechodnie ujęli rzecz dosadniej: „Gdyby mój syn, tobym chyba zabił. Już wolałbym, żeby był złodziejem albo alkoholikiem. Co lepsze: syn pedał czy córka panna z dzieckiem? Już prędzej wnuk bękart"38.

\section{$4 \cdot$}

Ponad rok po łódzkiej premierze, w listopadzie 1982 roku, Mikołaj Grabowski wystawia Trans-Atlantyk w Teatrze im. Juliusza Słowackiego w Krakowie. Gonzala gra ponownie Jan Peszek, a Ojca - Władysław Dewoyno. Pozostała obsada jest zmieniona. W marcu 1989 roku zostaje wznowiona łódzka inscenizacja, Witolda gra tym razem Mikołaj Grabowski, ale przy zachowaniu większości dawnej obsady. Tę wersję łódzkiego przedstawienia w 1991 roku przeniesiono do Teatru Telewizji - utrwalona zostaje w ten sposób w filmowym dokumencie rola Peszka, która musiała niewątpliwie podlegać przez ten czas pewnym metamorfozom (aktor jest starszy o dziesięć lat, ma za sobą wiele nowych doświadczeń aktorskich, wśród nich rolę homoseksualisty, hrabiego Łohoyskiego, w filmowej adaptacji Pożegnania

38 E. Berberyusz Seks heroiczny, czyli polski, w: Kto dzisiaj kocha..., wybór i red. H. Madana, Książka i Wiedza, Warszawa 1981, s. 99-100 i 104. 
jesieni). Zasadnicza struktura jego performansu wydaje się jednak pozostawać bez zmian ${ }^{39}$.

W recenzjach z łódzkiej prapremiery Gonzalo zostaje skojarzony z pewnymi formami kultury modernistycznej. Pisze o tym Jan Koniecpolski: „Gonzalo, dzięki znakomitej kreacji Janusza Peszka, jest czymś więcej niż działającym perfidnie homoseksualistą. Jest jakimś niezwykłym mistrzem ceremonii, pajacem, błaznem zmieniającym nieustannie kostiumy, przeobrażającym się z chwili na chwilę. Jego idee nabierają w pewnym momencie znaczeń ogólniejszych. Gonzalo okazuje się kwintesencją Kultury, Cywilizacji i jednoczesnym zaprzeczeniem obu tych wartości..." ${ }^{40}$.Zdaniem Ewy Piotrowskiej Gonzalo reprezentuje „kulturę w czystej, wypreparowanej niemal formie”41. Można domyślać się, że chodzi o modernistyczny model kultury, który umiejętnie zagospodarował - o czym była już mowa - utajone homoseksualne kody. Jak dowodził German Ritz ${ }^{42}$, polska literatura homoseksualna, maskując swoją obecność, wytworzyła silne i, co ważne, kanoniczne idiomy polskiego modernizmu w twórczości Gombrowicza, Iwaszkiewicza, Andrzejewskiego.

Gonzalo Peszka dokonuje jednak demistyfikacji tego modelu, wskazuje na działające wewnątrz niego systemy opresji, dyskryminacji, cenzury, które w klasycznym modelu homoseksualnej literatury modernistycznej powinny zostać niewidzialne lub zyskać zaszyfrowany kształt jako siły psychiki, losu. Tak chwalona przez recenzentów giętkość aktora, elastyczność, gotowość do przywdziewania różnych masek przypisywana była przez nich przede wszystkim jego homoseksualności. Można jednak odwrócić sytuację zgodnie z logiką zaproponowaną przez George'a Weinberga - to otoczenie wymusza na Gonzalu wypracowanie sztuki przetrwania w homofobicznym środowisku. Peszek rozgrywa ten temat świadomie i precyzyjnie od samego początku, od pierwszej rozmowy z Witoldem. Chcąc wkraść się w jego łaski, próbuje brać go na litość, zwierza się z udręki bycia homoseksualistą. Już sama fizyczna bliskość obu mężczyzn jest czymś niepokojącym, niewygodnym dla jednego z nich. Peszek zaczyna serio, intymnie. Opowieść o codziennych wędrówkach po ciemnych zaułkach miasta w poszukiwaniu partnerów seksualnych,

39 Jan Peszek grał także Gonzala w późniejszych inscenizacjach Mikołaja Grabowskiego (Tango Gombrowicz, Stary Teatr, 2003, oraz Trans-Atlantyk, Stary Teatr, 2008), były to jednak zupełnie inne propozycje interpretacji postaci Gonzala.

J. Koniecpolski Pomiędzy Scyllq i Charybdq , „Polityka” 1981 nr 42, s. 10.

E. Piotrowska „Kwartet” czyli o świadomości i bezmyślności, s. 40. 
o wiecznym niezaspokojeniu, lęku przed pobiciem i okradzeniem brzmi autentycznie. Wspomnienie niekończących się pogoni za młodymi chłopakami rozgrzewa go, rozpala. Gdy Witold, próbując się zdystansować wobec zbytniej bliskości Gonzala, okazuje mu konwencjonalnie wyrażone współczucie - ten gwałtownie wybucha, wygłaszając pochwałę swojego losu. Stawką jest przez cały czas pragnienie seksualne wraz z zagrażającymi mu okolicznościami zewnętrznymi. Litość również jest tutaj czymś niepożądanym, krępującym popęd. Gonzalo, zbliżając się do Witolda, czyniąc go wspólnikiem i powiernikiem, wyczuwa w nim ukrywającego się homoseksualistę, stara się jednak równocześnie rozbroić jego homofobiczne lęki, nie chce go demaskować. Złożoność roli Peszka została uwydatniona przez recenzentów dopiero po premierze krakowskiej:

Peszek w pierwszych scenach gra Gonzala naprawdę nieszczęśliwego, gra „puta” z bolesną świadomością ulegającego swoim skłonnościom. Transformacje jego są ostrożne, mądrze i oszczędnie stopniowane środkami tylko aktorskimi po to, by w części drugiej oszołomić zmieniającymi się kostiumami, zaskakującymi twarzami tej samej postaci. Peszek ma rzadką w naszym teatrze technikę aktorską, niezbędną przy wszelkiej deformacji. Świadomość gestu, swobodne władanie głosem i ciałem umożliwia mu pełne realizowanie Gombrowiczowskiego „podawania siebie", czyli samokreacji na użytek innych. Jego Gonzalo od pierwszej sceny panuje nad naszym bohaterem, bezbronnym wobec bezbłędnie zagranych argumentów przeciwnika. Jest to Gonzalo świadomie stosujący formę, stale badający efekt kolejnych masek i coraz bardziej pewny zwycięstwa. Postać to konsekwentna i zagrana z błyskotliwą brawurą. I dlatego walka Gonzala o Ignaca skazana jest z góry na powodzenie. Ignac nie ma alternatywy. ${ }^{43}$

Ten tak żywy opis roli Peszka stworzony przez Bożenę Winnicką nie wyjaśnia jednak, do czego Gonzalo dąży, co stoi na przeszkodzie realizacji jego pragnień, skąd bierze się jego zdolność „,samokreacji na użytek innych”. Recenzentka uniwersalizuje gejowski performans Peszka, tylko w pierwszym zdaniu wskazując na konkretne doświadczenie homoseksualnego mężczyzny żyjącego w homofobicznym społeczeństwie. Aktor natomiast nie zapomina o homoseksualnym ciele swojego bohatera w żadnym momencie. W scenach

B. Winnicka „Trans-Atlantyk" na wielkiej scenie, „Życie Literackie” 1982 nr 5, s. 7. 
z Witoldem nie przestrzega reguł zachowania, jakie narzucają wzorce męskości: obejmuje, przytula się, patrzy z bliska w oczy, dotyka ustami ucha, opiera głowę na ramieniu, przybliża twarz jak do pocałunku. Gdy Witold spluwa na niego, Gonzalo wyciera machinalnie twarz, nie okazując żadnych emocji, najwidoczniej oswojony z gestami agresji i obrzydzenia.

Premiera krakowska Trans-Atlantyku odbyła się niemal rok po wprowadzeniu stanu wojennego, w atmosferze żałoby po zdławionej rewolucji. Być może dzięki temu emancypacyjny potencjał postaci Gonzala zostaje teraz wyraźniej dostrzeżony:

Można też zerwać z tym wszystkim. Stać się Francuzem, Włochem, Niemcem, Argentyńczykiem. Nowy, kolorowy świat jest tak kuszący i bogaty! W Trans-Atlantyku symbolem tej nowości jest Gonzalo, argentyński milioner (a przy tym pederasta). Kolorowy jak papuga, bez smaku i bez sensu urządzający swój kapiący bogactwem pałac, mający w nosie jakąkolwiek tradycję, zapatrzony w teraźniejszość i - ewentualnie - przyszłość. Przeciwstawiający polskiej, z namaszczeniem przywoływanej Ojczyźnie karykaturalnie brzmiącą... Synczyznę... Liczy się dziś, jutro. Precz z przeszłością. Ważne są pieniądze i zabawa. Patriotyzm? Honor? To furda! Jak trudno porozumieć się z takim Gonzalesem... Więc co? Wracać?.... ${ }^{44}$

Prawdziwie niebezpieczne dla polskiej tożsamości okazują się konsumpcjonizm Zachodu oraz kultura masowa, które Gonzalo tutaj reprezentuje. Wtrącona w nawiasie uwaga o jego pederastii wzmacnia wprawdzie efekt obrzydzenia wobec perspektywy wynarodowienia, nie jest jednak kluczowa dla postrzegania postaci. Gonzalo mimo pederastii staje się dla widowni ucieleśnieniem lepszego świata. Tym razem sceniczny triumf Peszka i ideologiczne zwycięstwo Gonzala wydają się bezapelacyjne - choć gorzko komentowane przez recenzentkę. Odwołanie się do homofobii widzów nie staje się tutaj, jak w reakcjach na łódzką inscenizację, zręcznym zagraniem pozwalającym rozbroić gejowski performans Peszka. Ujmijmy to syntetycznie: łódzka publiczność gotowa była godzić się z konserwatywną ideologią reprezentowaną przez Ojca, aby chronić się przed demoralizującym wpływem Gonzala; krakowska podąża za Gonzalem jako obietnicą lepszego, barwniejszego życia - gotowa przełknąć jego odmienność seksualną wbrew własnym odczuciom i nastawieniom. 
Do wyjątkowych świadectw gejowskiego performansu Peszka należy opublikowana na łamach „Polityki” recenzja Tomasza Raczka, dzisiaj geja po publicznym coming oucie, wtedy jeszcze nieujawniającego swojej orientacji seksualnej. Zawiera cenne ślady odbioru spektaklu w perspektywie tożsamościowej. Raczek w pierwszym posunięciu rozbija fikcję jednolitej heteroseksualnej widowni.

Staromodna sala Teatru im. Słowackiego pełna jest dzisiaj rozentuzjazmowanych Ignaców, którzy coraz goręcej przyjmują racje Gonzala... W dzisiejszych Ignacach, po wieloletnich zabiegach, „odczarowano” polskość. Więc też ich sny o ojczyźnie, państwie i społeczeństwie są na pewno bliskie deklaracjom Gonzala. Zresztą i z nim spotykają się, mażąc napisy w owych publicznych i ciemnych świątyniach wszelkich słabości. ${ }^{45}$

Wskazani przez Raczka „Ignacowie” nie są po prostu, jakby mogłoby się na pierwszy rzut oka wydawać, przedstawicielami młodego pokolenia Polaków - są młodymi polskimi gejami, których Raczek czyni najżywiej reagującymi odbiorcami performansu Peszka. Kwestia o mazaniu napisów w „publicznych i ciemnych świątyniach wszelkich słabości" jest słabo zawoalowaną aluzją do seksu pikietowego, uprawianego w parkach i szaletach. Gonzalo w recenzji Raczka przestaje być Argentyńczykiem, staje się Polakiem (bo to z nim przecież spotykają się na pikietach młodzi geje). Odbierany w tożsamościowej perspektywie, Gonzalo w wykonaniu Peszka rysuje się nieco inaczej niż w pozostałych recenzjach. Nacisk jest tutaj położony nie na „perfidię”, ,śliskość" i „wyuzdanie”, lecz na seksualny czar aktora, działający na Ignaców na widowni: „Peszek jako Gonzalo, choć występuje w zwiewnych szlafroczkach i krótkich spódniczkach, zachowuje przecież umiar i «męskość», potrzebne, by uwiarygodnić tę postać. Ten Gonzalo jest jurny i prowokatorski, jest naprawdę niebezpieczny"46. W ten sposób gejowski performans Peszka znajduje wreszcie widzów odczytujących jego emancypacyjny przekaz.

Powieść Gombrowicza przepuszczona przez dyskursywne praktyki teatru silniej niż w recepcji literackiej odsłania swoje wielorakie osadzenie w kulturze homofobicznej. Dyskurs krytyczno-literacki jest skłonny rozwijać przede wszystkim „idealne znaczenia” i stroni od badania realnych praktyk lektury oraz towarzyszących im „brzydkich uczuć”. Reakcje na performans Jana Peszka

45 T. Raczek Orzełczy reszka, „Polityka” 1982 nr 14, s. 9.

46 Tamże. 
pozwalają uchwycić tryby odczytywania Trans-Atlantyku bez idealizującego filtra. Jeśli Gombrowicz osią konfliktu i napędem fabuły czyni homoseksualność Gonzala, należałoby zapytać o możliwe realne modele lektury jego powieści w społeczeństwie kultywującym homofobiczne wzorce: zarówno o potencjał emancypacyjny, jak i mobilizację wrogiego nastawienia wobec seksualnej odmienności. A także o całe spektrum lektur pomijających ten temat, przenoszących uwagę gdzie indziej. Rita Felski, pytając o pożytki płynące z literatury, postulowała, aby uwolnić nasze sposoby czytania od nadmiernie sformalizowanych rygorów interpretacji:

Izolując literaturę od wszystkiego dookoła, krytycy nie potrafią wyjaśnić, w jaki sposób dzieła sztuki wychodzą poza świat społeczny i znów do niego wracają. Podkreślając wyjątkowość literatury, pomijają równie istotne rzeczywistości jej powiązań. Podziwiając niewysłowione i enigmatyczne właściwości dzieł sztuki, nie oddają sprawiedliwości konkretnym sposobom przenikania takich dzieł do naszego życia i wpływania na nie. ${ }^{47}$

Gejowski performans Jana Peszka można czytać właśnie w perspektywie „rzeczywistości powiązań” - jako otwierający wielokierunkowe przepływy emocji, afektów, nastawień, ingerujący w dyskurs publiczny na temat homoseksualności. Odbiór jego występu scenicznego nie polegał bowiem na interpretacji, lecz zajmowaniu stanowiska.

47 R. Felski Uses of literature, Blackwell Publishing, Malden-Oxford 2008, s. 5. 


\section{Abstract}

\section{Grzegorz Niziołek}

JAGIELLONIAN UNIVERSITY (CRACOW), AST NATIONAL ACADEMY OFTHEATRE ARTS (CRACOW)

Shamelessness: Jan Peszek's Gay Performance

Based on an analysis of Jan Peszek's gay performance in the 1981 production of Witold Gombrowicz's Trans-Atlantyk Niziołek constructs a theoretical notion of the micro-event in the public sphere, defined as an affective intervention that touches on the shell of accepted social discourses on homosexuality in the conditions of pre-emancipation culture. In the case of public theatre, an institution founded on the enlightenment project, this sort of micro-event deconstructs the isomorphism of stage representations and of public discourse. The affective power of performance appears as a loss of control over the constructed meaning of the spectacle and the process of reception - a loss of control that threatens the very foundations of communication.

\section{Keywords}

public sphere, theatre, homophobia, emancipation, performance 